\title{
New Deal Labor Policy and the Containment of Radical Union Activity
}

\author{
By: Rick Hurd
}

\section{Abstract}

New Deal labor policies were designed with the stability of the capitalist economy in mind. Their pro-union provisions responded to labor militance and served to head off the formation of a radical working-class movement. The National Labor Relations Act established procedures which encouraged unions to pursue peaceful collective bargaining rather than a more activist course. Although the enforcement of pro-union policies was weak, the fact that they were adopted gave the impression that the state was sensitive to worker interests. When the crisis ended with the onset of World War II, the state reverted to an approach which more directly restricted worker militance.

There is widespread agreement among radicals that the state serves the needs of capital. If this position is to be defended, reforms adopted by the state which seems to be pro-working class must be explained. Of particular interest in this regard is the federal labor policy of the New Deal which, at least on the surface, offered no advantage to capital. By most traditional accounts, the 1935 National Labor Relations Act (NLRA) placed the state on the side of labor and laid the foundation for an unprecedented growth in union membership which continued for more than ten years

If the NLRA and other labor policies of the 1930s were as favorable to the working class in impact as in appearance, then the radical analysis of the role of the state should be reevaluated. This would lend credence to the social democratic position that progressive reforms are possible within capitalism.

It is argued below that the labor policies adopted during the Great Depression were necessary responses to the crisis in capitalism. If the working class was to be persuaded that the capitalist system was worth preserving, it was necessary to demonstrate that the state was willing to be responsive to worker concerns. In actuality, the policies were more progressive in appearance than in effect. Not only was the NLRA poorly enforced, but also the availability of legal remedies to working class problems tended to sap worker militance and reduce the intensity of the class struggle. Furthermore, as soon as the crisis was over and the pressure was off, state labor policy was revised and overt repression of working class militance was reinstituted.

The essential flaw in the traditional analysis is its focus on the political-legal process leading to the passage of particular acts by the Congress and on the judicial interpretation of these acts. ** Some liberal historians have noted that the legislation was intended to preserve capitalism, but because they accept this as a legitimate goal their analysis stops there. ${ }^{1}$

This article is one step towards a radical reevaluation of the historical development of federal labor legislation. It points to an alternative explanation of the evolution of labor law. This explanation starts from the view which identifies Congressional action as a formal expression of the needs of the economic system. It is the capitalist economy that is the driving force behind the regulation of labor.

\section{Analytical Framework}

This paper accepts the thesis that the state serves the interests of capital. This is not to say that capitalists control the state apparatus, but rather that the state is committed to the preservation of the capitalist system, making such direct control unnecessary. 
In fulfilling its system preserving duties, the state performs two (sometimes conflicting) functions. First, the state directly aids capital in its drive for profits, for instance by repressing working class movements. Second, the state attempts to maintain an atmosphere of social harmony in order to assure that capital operates in a non-hostile environment. Thus the state will sometimes adopt policies which respond to working class needs and demands. However, such policies are reformist, projecting the appearance of change without actually re-ordering society. ${ }^{2}$

The following evaluation of federal law can be briefly summarized in terms of the functions of the state. Prior to the 1930's the repressive labor policy of the state overtly supported capital. During the 1930's potential and actual working class militance necessitated a shift in policy and the state adopted reforms which appeared to be pro-worker. However, these policies allowed working class activity which conflicted with the profit needs of capital, and the developments of the 1940's and 1950's reflect an attempt by the state to balance its two functions.

\section{Labor Policy Before the Great Depression*}

The Sherman Act of 1890 was antitrust legislation ostensibly aimed at curbing the economic power of capital. However, the "restraint of trade" provisions were interpreted by the Supreme Court as applicable to various forms of economic pressure employed by unions. It became standard practice for federal courts to issue injunctions against strikes, boycotts, and picketing. ${ }^{3}$

Federal court injunctions also restricted union organizing activity. Prior to the 1930's it was common for capital to require that before being hired workers sign contracts agreeing not to join a union. Organizing drives among workers who had signed these "yellow dog contracts" were considered to be attempts to induce breach of contract and were enjoined by federal courts. ${ }^{4}$

The labor injunction placed the state clearly on the side of capital. This overt assistance was possible because of the nature of the labor movement in the United States.

The conservative American Federation of Labor (AFL) gained control of the labor movement in the late nineteenth century by practicing "pure-and-simple" business unionism. It restricted its organizing activities almost exclusively to craft workers and concentrated on raising their wages, ignoring most production workers and eschewing political activity. Because the AFL was not interested in building a class conscious union movement, its leaders were eventually granted a certain amount of status and access to business and government officials. AFL leaders, then, were recognized as spokespersons for the working class in return for their continued support of capitalism.

Although the general tendency was for state labor policy to be overtly pro-capital, three exceptions warrent brief mention. First, in response to the AFL's lobbying efforts, the Clayton Act of 1914 included clauses which appeared to limit the application of antitrust legislation against unions. This gesture by the state was effective, prompting Samuel Gompers, president of the AFL, to proclaim that the act was "Labor's Magna Carta " . ${ }^{5}$ It was, as it turned out, far from a Magna Carta because its loose wording enabled the courts to interpret the act to the benefit of capital. A supreme court ruling allowed the continued use of injunctions in most labor conflicts. ${ }^{6}$ This turn of events did not politicize labor, however, as the AFL blamed the judiciary rather than capitalism.

Second, during World War I the War Labor Board secured the AFL's cooperation in the war effort by protecting labor's right to organize and by promoting collective bargaining. But as soon as the war was over, War Labor Board protections were withdrawn. ${ }^{7}$ Capital weathered a big strike year in 1919 with the help of the Bureau of Investigation of the Department of Justice. Crucial here was a red scare waged by capital and the state with the cooperation of AFL leaders, which decimated the progressive ranks of labor. ${ }^{8}$ The 1920's witnessed a substantial increase in the use of labor injunctions.

\footnotetext{
${ }^{* *}$ Definitions are included in Appendix B.
} 
Third, the Railway Labor Act of 1926 protected labor's right to organize in that industry in return for limitation of the right to strike. ${ }^{9}$ In this act, supported by both unions and capital, the state foreshadowed by twenty years its current policy of balancing its functions of aiding profits and preserving social harmony.

\section{The Norris La Guardia Act}

During the 1930's the state altered its labor policy. The Norris-LaGuardia Act of 1932 made yellow dog contracts unenforceable and strictly limited the power of federal courts to issue injunctions in labor disputes. ${ }^{10}$

The AFL had been lobbying for anti-injunction legislation since the early 1900 's with a consistent record of failure. In 1908 the AFL-supported Peare Bill got nowhere. The Clayton Act anti-injunction language was ineffective. In 1927 the Shipstead Act died. The Norris Act met the same fate in 1928. Then in 1932 the Norris-LaGuardia Act, essentially the same as its predecessors, passed the Senate 75 to 5 and the House 362 to 14 , and was signed by Hoover. ${ }^{11}$

The reason for this reversal was the changed economic climate. The depression heightened the potential for class conflict and forced the state to pay more attention to the demands of labor. Earl Michener, a conservative representative from Michigan who was a leading opponent of most reformist legislation, supported Norris-LaGuardia because the AFL had "done more than any other group or class of our people in maintaining peace and order during the depression"12 Other representatives joined in the support of the legislation because of the AFL's non-militance and opposition to communism.

Capital did not offer stiff opposition to Norris LaGuardia. One reason was that they hoped for relief from the courts. When President Hoover signed Norris-LaGuardia he released an opinion written by the Attorney General implying that it was unconstitutional. In fact, the act was not fully effective until the Supreme Court affirmed its constitutionality in $1938 .{ }^{13} \mathrm{~A}$ more important reason for capital's apparent complacency was the availability of the same service from another source. Norris-LaGuardia restrictions affected only federal courts; state courts continued to issue injunctions and restraining orders against union activity.

\section{The National Industrial Recovery Act}

In the Spring of 1933 the economy was staggering. National income was less than half of its 1929 level, unemployment was over twenty-five percent, thousands of banks had failed, farmers were going on "holidays" to protest falling food prices, and the unemployed were organizing and becoming more militant. In the words of Arthur Schlesinger, Jr., "whether revolution was a real possibility or not, faith in a free system was plainly waning. Capitalism, it seemed to many, had spent its force...." 14

The New Deal is best seen as a necessary response to this crisis in capitalism. Roosevelt made no secret of the fact that the programs of his administration were designed to save the capitalist - system. The centerpiece of the $\mathrm{N}$ e w Deal was the National Industry Recovery Act, which provides direct state support to capital. The state would help capital form trade associations, which would fix prices and outputs so that profits could be maximized. ${ }^{15}$

In the spring of 1933 William Green, president of AFL, threatened a general strike if legislation imposing a thirty hour work week were not enacted. ${ }^{16}$ Partly in response to such threats by labor, Roosevelt got the AFL involved in the drafting of the Recovery Act. The result was section 7a, which set minimum conditions of employment and affirmed the right of workers to organize. The labor provisions were included to buy union bureaucrats' support for the $\mathrm{N} \mathrm{e} \mathrm{w} \mathrm{Deal,} \mathrm{and} \mathrm{their} \mathrm{cooperation} \mathrm{in} \mathrm{the} \mathrm{fight}$ to save capitalism.

The national Chamber of Commerce and the AFL made an agreement that the Chamber of Commerce would accept the labor sections of the Recovery Act and the AFL would support its pro- 
capital features. ${ }^{17}$ Capital was willing to make this deal because it was convinced that the act allowed the formation of company unions.

Under the Recovery Act, trade union membership did increase, especially in mining and clothes manufacturing where vigorous organizing campaigns were conducted under the slogan "The President wants you to join a union" ${ }^{18}$ From 1933 to 1935 union membership increased by 900,000 to 3.6 million, although this was only 180,000 higher than the 1930 level and actually 500,000 less than 1929 membership. Of the increase, four unions accounted for almost 700,000 - the United Mine Workers, the International Ladies Garment Workers, the United Textile Workers, and the Amalgamated Clothing Workers.

During the same period company unions sprang up everywhere as capital sought ways to avoid the labor provisions of the act. Company unions grew even faster than trade unions, with total membership reaching 2.5 million in $1935 .{ }^{19}$

The National Labor Board (NLB), established to implement the labor provisions of the bill, had virtually no enforcement power and section 7 a was widely evaded. ${ }^{20}$ Although capital was permitted to disobey the N L B at will, the states commitment to a pro-capital application of the Recovery Act was not completely exposed until the spring of 1934. A controversy in the automobile industry over the legitimacy of company unions settled on March 25, one day before a scheduled strike, when Roosevelt announced that he interpreted the Recovery Act to permit company unions. As observed by labor historian Irving Bernstein, "After March 25, 1934, determined unionists in the un-organized industries recognised that they would win bargaining rights not by invoking the law but by showing their own strength." ${ }^{21}$

Later in the spring, with worker militance running high and a steel strike threatening, Roosevelt announced a plan to reorganize the National Labor Board to make it more effective. This move helped avert the steel strike, but the reorganization did little to benefit labor. ${ }^{22}$

With labor's faith in the Recovery Act undermined, workers began to rely more on their own collective strength. 1934 was the biggest strike year since the early 1920's, with four strikes of special importance. A spring strike in Toledo against the Electric Auto-Lite Company was supported by massive demonstrations of the unemployed, several times erupted into violence, and very nearly evolved into a general strike. A truckers strike in Minneapolis lasted most of the summer, practically closed down the city, and at times verged on class warfare. ${ }^{\dagger}$ In San Francisco, a longshoring strike which started in May escalated into a general strike in July after a day long battle between police and strikers. In September a massive strike by 376,000 textile workers shut down that industry on the entire east coast, and ended only after the President intervened and the National Guard was called out in states from Rhode Island to Mississippi to break the strike. ${ }^{23}$

The increasing militance and class consciousness of the rank and file was being forced on reluctant national union officers. The successful strikes Toledo and Minneapolis were led by Trotskyites, and in San Francisco by Stalinists. ${ }^{24}$ The state was backed into a corner as worker disaffection forced the $\mathrm{N}$ e w Dealers to come up with a labor policy that would protect capital by effectively limiting the radicalization of the working class. The response was the National Labor Relations Act of 1935.

\section{The National Labor Relations Act}

The NLRA, also known as the Wagner Act, asserted the right of workers to form unions, and to protect this right it outlawed certain activities of capital. The forbidden acts, designated unfair labor practices, included the following:

\footnotetext{
${ }^{\dagger}$ For example, in the "Battle of Deputies Run" on M ay 22 striking workers soundly defeated the police and the "Citizen's Army," composed primarily of Minneapolis' social elite. Fifty were injured and two were killed, including a vice-president of American ball Company. Bernstein, Turbulent Years, p.238.
} 
1. interference by capital with workers' attempts to form a union,

2. the establishment of company unions,

3. discrimination against union members,

4. refusal by capital to bargain about terms of employment with unions selected by a majority of the workers.

To enforce the act the National Labor Relations Board (NLRB) was created. The N L R B was to hear and decide cases involving unfair labor practices and was to conduct elections so that workers could determine whether or not a union would represent them. ${ }^{25}$

The N L R B W3.S designed to sustain the "reasonable" collective bargaining approach to unionism practiced by the AFL, and was strongly supported by union bureaucrats. The former chairperson of the National Labor Board, Lloyd Garrison, favored the bill "as a safety measure, because I regard organized labor in this country as our chief bulwark against communism and other revolutionary movements." ${ }^{26}$

The NLRA was designed to assure industrial peace, as pointed out by Roosevelt when he signed the bill: " By providing an orderly procedure for determining who is entitled to represent employees, it aims to remove one 01 the chief causes of wasteful economic strife.,27

These statements by Garrison and Roosevelt capture the essence of the system-preserving nature of the NLRA. The NLRA was supportive of the AFL. It provided a legal sanction for unions, and established a peaceful method by which workers could choose democratically whether or not to have a union.

With the NLRA there would be a peaceful alternative to organizing strikes. ${ }^{\ddagger}$ In addition, workers would be likely to credit their success in part to government beneficence and the $\mathrm{N}$ e $\mathrm{w}$ Deal rather than learning to trust themselves. Because the NLRA encouraged the brand of business unionism practiced by the AFL, it relieved the threat of a labor movement opposed to capitalism. Without the NLRA, workers would have no recourse except to strike and force their employer to recognize their union. This type of action, if successful, would establish a militant tradition and help workers realize the potential of their collective strength. Once they recognized their collective potential, the formation of a radical working class movement would be possible. The left wing leadership of the major strikes of 1934 was a clear indication that workers were willing to become part of such a movement.

The NLRA, then, was antiworking class in spite of the fact that it was pro-union. By supporting business unionism it helped undermine the radicalization of the working class. This system preserving action was taken by the state in spite of opposition from many capitalists, wh o would have preferred more direct repression of working class activity.

The National Association of Manufacturers (NAM) opposed the NLRA because it outlawed company unions and because the other provisions went beyond the Recovery Act and would cause an annoyance for capital. ${ }^{\S}$ Some capitalists agreed with Garrison and Roosevelt and supported the NLRA. Most supported the N A M position, but were not overly concerned when the NLRA passed because they confident that it would be declared unconstitutional by the courts. During the preceeding year twenty federal courts had ruled in Recovery Act cases that the federal government could not exercise control over local production. Based on these decisions capital deduced that the courts would not allow Congress to regulate the labor-management relations arising from production. The case for unconstitutionality was boosted when the Supreme Court struck down section I of the Recovery Act, including the labor provisions, while the NLRA was still being debated in Congress. ${ }^{28}$ Interestingly, the American Civil Liberties Union opposed the NLRA because of the conviction that the federal government would not treat unions fairly in its enforcement of the act,

\footnotetext{
${ }^{\ddagger}$ Organizing strikes attempt to force the employer to recognize a specific union as representative for his or her employees.

${ }^{\S}$ The passage of the NLRA in the face of N A M opposition is not a deviation by the state from its procapital activities. Rather, it reflects a difference of opinion over how much attention should be paid to social harmony vis a vis profits. Frequently individual capitalists or groups of capitalists will support policies which are in their o $\mathrm{w} n$ selfinterest, rather than alternative courses of action (such as the NLRA) which better serve the needs of capitalism as a whole.
} 
and because of the concern that labor would be "lulled into a sense of security" and lose sight of the fact that union militance was the only way to support the right to strike. ${ }^{29}$

\section{Experience under the NLRA}

A close look at the events of 1935 to 1947 reveals that the legal climate was not as favorable to labor as a cursory review of the NLRA might indicate.

The enforcement of the NLRA was assigned to the National Labor Relations Board. However, most of the board's time between 1935 and 1937 was devoted to defending the constitutionality of the NLRA. In the meantime most employers ignored the act. During the first two years capital abided by NLRA unfair labor practice decisions in only four cases. Furthermore, capital frequently secured federal court injunctions to prevent the N L R B from enforcing the act. ${ }^{30}$

On April 12, 1937, the Supreme Court upheld the constitutionality of the NLRA. However, challenges by capital continued until January 31,1938 , when a Supreme Court decision forbade federal courts from enjoining N L R B activities. After these rulings capital switched tactics. The N A M encouraged employers to evade the law with every means possible, suggesting ways to transfer company unions into "independent unions" as one course of action. ${ }^{31}$ The risk of evasion was low because the penalty for failure to comply with the NLRA was typically only an order to cease unlawful practices, or to rehire workers who had been fired illegally.

In response to pressure from capital, Congress diverted the N L R B from its enforcement duties with three full scale investigations between 1937 and 1941. In addition, the state did not fund the N L R $B$ adequately, assuring a long delay between the filing of a complaint and a decision. In 1937-38 the wait was slightly over a year, and by 1946-47 the delay was more than a year and a half. ${ }^{32}$ Following an N L R $B$ decision, capital could further delay enforcement by appealing to the federal courts.

After a detailed review of N L R B activities from 1935 to 1947, Millis (who chaired the N L R B from 1940 to 1945) and Brown concluded, "The most important deficiency was that the sound and democratic rights (of workers) under the Act were never fully protected The Board failed vigorously to push for enforcement and compliance with the act." ${ }^{33^{* *}}$

Labor did not wait for the N L R B to enforce the NLRA. In the fall of 1935 a group of industrial unions from the AFL formed the Committee for Industrial Organization, later to break with the parent federation and change its name to the Congress of Industrial Organizations (CIO). ${ }^{34}$ Militant rank-and-file movements were already underway in the automobile, steel and rubber industries but the craft oriented AFL had done little to help the workers organize. The $\mathrm{ClO}$ immediately filled the void, and rode the wave of worker militance throughout the rest of the depression.

The most effective tactic employed by $\mathrm{ClO}$ unions was the sit-down strike - an illegal takeover of property not protected under the NLRA. ${ }^{+\dagger}$ The biggest sit-down year was 1937 when almost 400,000 workers were involved in approximately 500 sit-down strikes. ${ }^{35}$

In the automobile industry sit-down strikes against General Motors (January-February, 1937) and Chrysler (March-April 1937) forced them to sign contracts with the United Automobile Workers,

\footnotetext{
${ }^{* *}$ This demonstrates clearly the reformist nature of the NLRB and the variety of options open to the state to support capital. Many individual capitalists chose to ignore the law while waiting for a judicial reversal of the statute. $\mathrm{W}$ h e this failed to materialize, capital secured weak enforcement of the NLRA, and simultaneously laid the foundations for a future change in official policy.

${ }^{++}$The willingness to disregard the law when tactically advantageous was forced on the ClO leadership by a militant rank-and-file. Though John L. Lewis. Philip Murray, and ocher CIO bureaucrats supported many spontaneous worker actions, they preferred the more legalistic alternative offered by the N L R B. The CIO clearly did a better job of taking advantage of worker discontent than the $\mathrm{AFL}$, but was equally committed to the system politics $\mathrm{ClO}$ leaders were strong supporters of Roosevelt and heavily involved in the formation of $\mathrm{N}$ e w Deal policy. See Preis. Chapter 6
} 
ClO. Hudson, Packard, and Studebaker saw the writing on the wall and quickly reached agreements with the Auto Workers, the latter two after N L R B elections. In the rubber industry workers began using sitdown strikes in early 1936 to fight specific actions by capital, such as assembly line speed-ups or discrimination against union members. With unionism thus firmly entrenched, conventional strikes successfully forced recognition of the United Rubber Workers, ClO by Firestone in April 1937 and Goodrich in M a y 1937. In 1936 the Steel Workers Organizing Committee, ClO, organized the workers at United States Steel by infiltrating its company union (though declared illegal by the NLRA, company unions still dominated many industries). With its workers obviously organized, and with sit-down strikes sweeping the country, United States Steel chose the reasoned approach and recognized the ClO union without a strike in March 1937. Elsewhere in steel, workers at Jones and Laughlin refused a company offer of N L R B elections and successfully struck for union recognition in M a y $1937 .{ }^{36}$

Unions grew rapidly in the later 1930's because workers began to challenge capital directly and effectively. Sit-down strikes and a vigorous organizing drive by the $\mathrm{ClO}$ were responsible for much of the growth. Total union membership rose from 3.6 million in 1935 to 10.2 million by $1941 .{ }^{37}$ The experience of the period indicates that, with a few exceptions, capital obeyed the NLRA only when forced to by strong unions.

Once militant union action won concessions and contracts from major employers, the N L R B election procedures provided to other employers in the industry or geographic area a peaceful arena in which to wage their struggle against unionization. This was often preferable to making a choice between conceding without a fight or suffering through a long battle. Even if the union won the election, at least the conflict would have been settled peacefully. With such a beginning the danger of having to face an angry union leadership would be lessened.

This "legal organizing; through elections conducted by the N L R B undoubtedly speeded the spread of unionism, but at the expense of establishing a militant tradition of economic gains won by direct worker action. As Cohen put it, "Perhaps the greatest contribution of the Wagner Act was the successful establishment of procedures to minimize the amount of industrial conflict associated with a massive drive for unionization." ${ }^{38}$

Without the NLRA there undoubtedly would have been more militance in the 1930's. The lengthy crisis was driving wages lower and lower, and working class dissatisfaction with the economic system was increasing. Workers had little respect for a private property oriented legal system designed to protect capitalism. In this atmosphere overt repression of unions by the state would only increase militance and heighten the potential that a radical working class movement would evolve. The NLRA protections, as weak as they were, gave workers some feeling that the state was responsive to their needs. And the NLRA provisions for union elections and the handling of unfair labor practice complaints provided a non-militant option for workers to register their discontent.

Capital spent much of the period groping for a new strategy for its confrontations with labor. The increased militance of workers made the outright repression of earlier periods ineffective. A growing number of capitalists were beginning to see the advantages of collective bargaining. Leading capitalists expressing this view were Gerald Swope of General Electric and Cyrus Ching of United States Rubber. ${ }^{39}$ The formal bureaucratic procedures of the N L R B were slow, peaceful ways to settle labor disputes. The NLRA, though nominally pro-labor, was drawing unions away from militant tactics, both where capital chose to comply and where AFL or CIO bureaucrats met employer resistance with appeals to the N L R B rather than relying on worker militance. Examples of the former are General Electric and United States Rubber, where a receptive attitude resulted in union contracts without strikes and with virtually no turmoil in 1938. Examples of the latter are Little Steel and Ford, where unfair labor practice cases filed by $\mathrm{CIO}$ unions were tied up in the N LR B and the courts from 1937 to 1941 before resolution. After the $\mathrm{C}$ I O won the Little Steel court struggle, N L R B elections resulted in contracts with Bethlehem, Inland, Republic, and Youngstown without a strike. At Ford the workers were not as patient as the union 
leadership and staged a spontaneous sit-down in August 1941, forcing the union to call a strike which broke Ford's anti-unionism before an N L R B election could be conducted. ${ }^{40}$

Capital eventually reached consensus, deciding that the NLRA should not be repealed but should be amended to better suit the needs of capital - union activity required more direction from the state. In 1939 both the N A M and the Chamber of Commerce adopted this line and began a careful and polished campaign to lay the foundation for a switch in state policy. Of particular importance was an anti-communist crusade, waged with newspaper advertisements and pamphlets and bolstered by hearings of the newly formed House Un- American Activities Committee; much of the propaganda was aimed at undermining the militant factions of the $\mathrm{CIO}^{41}$

\section{The Labor Management Relations Act}

In 1940 the House responded to capital's campaign with the Smith Act which included a number of restrictions on union activity. The reformist-oriented Senate however, was not yet convinced of the importance of altering labor policy and the final version of the bill included only minor modifications in N L R B procedures. ${ }^{42}$ The pressure for amendments to the N L R B subsided during World War II, as formal and informal controls such as the War Labor Board were employed to control labor militance. One pro-capital measure implemented during this period was the War Labor Disputes Act of 1943, which specifically limited the right to strike in war-related industry. ${ }^{43}$

The wartime restrictions were not totally effective, in spite of no-strike pledges from most A FL and $\mathrm{ClO}$ leaders. Particularly important were a nation-wide coal miners' strike in 1943 and a rash of wildcat strikes in the automobile industry throughout the war. ${ }^{44}$

When the war ended strike controls were lifted and worker militance erupted in earnest. 1945, 1946, 1947 were big strike years, with labor winning improved wages and working conditions in almost every major industry. There were more workers involved in strikes in 1945 and 1946 than at anytime during the depression. ${ }^{45}$

The militance of workers was not well received by capital or the state. Even the reform-oriented members of Congress who had drafted the NLRA were disturbed by the disruptions of the economy, and began to discuss the need for "equalizing" legislation to control the "abuse of power" by big unions. The unlimited use of peaceful economic weapons by unions no longer served the needs of capital. As noted by Cox, "In 1947 there were many who saw the danger of nationwide stoppages threat to the social system." 46

In an attempt to get capital and labor to voluntarily work together for the good of the economic system, President Truman had convened a labor-management conference in the fall of 1945 . The agents of capital and the union bureaucrats were able to agree on a few points (such as the benefits of peaceful collective bargaining and the need for a federal conciliation service) but not on others (such as management's right to manage). Disappointed at the failure of his attempt to secure voluntary cooperation between labor and capital and disturbed by the post-war strike wave, in January 1947 Truman proposed several amendments to the NLRA, including limitations on jurisdictional strikes and secondary boycotts. ${ }^{47}$

Throughout the spring of 1947 the agents of capital (N A M and Chamber of Commerce lawyers), working with House Republicans, drafted amendments to the NLRA. The resulting Hartley Act passed the House in April. A similar bill, the Taft Act, passed the Senate in May and the compromise Taft-Hartley Act (the Labor Management Relations Act (LMRA)) was accepted by both houses in June. ${ }^{48}$ The LMRA was not simply "equalizing" legislation. It placed restrictions on a wide variety of union activities, and demonstrated clearly the state's role as protector of capital.

The LMRA outlawed closed shops, required sixty days' notice before a strike, required a non- Communist oath from all union officials, allowed states to outlaw union shops, and made collective bargaining contracts enforceable in the courts. The LMRA also added a list of unfair labor practices for labor unions, including: 
1. organizing strikes,

2. jurisdictional strikes,

3. secondary boycotts,

4. featherbedding,

5. refusal to bargain with management.

Finally, the LMRA set up a complex procedure to deal with "national emergency" strikes; under this procedure, whenever the President decides that a strike endangers national health or safety, the strike can be enjoined by federal courts for 80 days. ${ }^{49}$

As might be expected, organized labor fought hard against passage of the LMRA. After it was enacted, the AFL held a special conference to decide how to answer capital's attack on labor. The conference passed the following resolution:

"The repeal of this notorious legislation shall be our fixed objective. We shall never be reconciled to the acceptance of this legislation. We shall oppose it - fight it at every step and every opportunity - until we succeed in our efforts to bring about its repeal. Our action in this respect will be based upon the fact that we regard the Taft-Hartley Bill as a slave measure, unAmerican, vicious and destructive of labor's constitutional rights" ${ }^{50}$

To achieve this objective AFL campaigned for Congressional candidates sympathetic to labor, and lobbied to bring about the repeal of the LMRA. But there has been no pressing need to pacify labor and the state has not shifted its policy. With the addition of a few more restrictions on union activity in 1959, the LMRA is still the centerpiece of labor law today.

The primary targets of the LMRA were worker militance and the spread of unionization. The LMRA sought to decrease worker militance by placing strict limits on picketing and striking activity and by outlawing secondary boycotts. It attempted to stop the spread of unionization by making organizing strikes illegal and by preventing established unions from exerting secondary pressures in support of organizing campaigns. The limitations on secondary pressures are probably the most important part of the LMRA because they limit the degree to which workers can support struggles in other industries and unions, thus hindering the development of a unified working class movement.

The LMRA hit the targets at which it was aimed. Union membership, which grew from less than seven percent of the labor force in 1935 to about 24 percent in 1947, changed little over the next twenty five years, accounting for slightly less than 23 percent of the labor force in 1970. Strike activity also declined, with the downward trend continuing through the 1960 's. ${ }^{51}$

The LMRA and the post World War II Red Scare, both emanating from the same source, combined to weaken the $\mathrm{ClO}$, which conducted a purge against radicals, expelled militant unions, and eventually merged with the AFL in $1955 .^{52}$ Established unions settled comfortably into the role of responsible business unionism.

Legalistic control of labor would not be possible if there existed a class conscious union movement willing to disobey the law when such action would benefit workers. The rank and file acceptance of legalistic control can be traced in part to the Red Scare and the improved material conditions of workers in the 1950's as compared to the 1930's. Equally important is the suppression of militance by union bureaucrats.

Leaders of most U.S. unions preach respect for the law because of their commitment to capitalism. In fact, union officials benefit directly from the increasing legalism in the collective bargaining area. The complexities of the collective bargaining contract are a convenient excuse for increased reliance on lawyers and other experts, and hence for bureaucratization of unions with the attendant centralization of control. In this atmosphere it is not surprising that union officials use the law and 
experts to rationalize their o $\mathrm{w} n$ conservatism. Nor is it surprising that they concentrate their attention on wages, where they can deliver the goods without threatening capitalism. ${ }^{53}$

\section{Concluding Comments}

As the economic crisis of the 1930's deepened, worker discontent grew. The militance of the working class throughout the period, especially from 1934 onward, required an effective response from the state. Rather than opting for outright suppression, which in all likelihood would have only fueled the flames of radicalism, $\mathrm{N}$ e w Dealers chose to make concessions to the working class. Most important, the official labor policy was supportive of union activity.

Working class gains during the Great Depression cannot be credited to $\mathrm{N}$ e w Deal policies.

Unions prospered to be sure. But, the NLRA and other labor laws were poorly enforced; capital obeyed them only when forced to by strong unions. The growth of union membership resulted from worker militance, not from protections offered by the state.

New Deal labor policy was designed to buy worker acceptance of capitalism. If the state demonstrated sympathy, the working class would be less likely to challenge the existing order. Furthermore, the policies supported the continued development of the type of unionism practiced by the AFL. Both the AFL and the $\mathrm{ClO}$ preferred the legalistic approach to union organizing encouraged by the NLRA. The tendency was to eschew direct action and to opt instead for N L R B elections, or where capital was obstinate to file unfair labor practice complaints with the N L R B. As a result the working class was taught to rely on the protection of the law rather than on their own strength. Although the $\mathrm{Ne}$ $w$ Deal contributed only marginally to the unionization of the working class, it did help shape the movement which evolved. It furthered the expansion of unions which worked within the economic system, thus helping to avert the possibility that a new, more radical, movement would form which proposed an alternative to capitalism. Once the crisis was over the state adopted a more obviously procapital approach, a clear indication that the $\mathrm{N} \mathrm{e} \mathrm{w} \mathrm{Deal} \mathrm{labor} \mathrm{policy} \mathrm{offered} \mathrm{short-term} \mathrm{concessions} \mathrm{only}$ in the interest of the long-term health of capitalism.

The information presented in the body of the paper lends support to the hypotheses that: (1) the role of labor law is to limit or direct union activity in ways consistent with the capitalist system; (2) the goal of the legislation is the containment of radical union activity; and (3) the direct involvement of the state in the ongoing struggle between labor and capital is necessary in order to protect the interests of capital.

\section{APPENDIX A}

\section{A Brief Review of the Traditional Analysis}

Industrial relations specialists are remarkably consistent in their explanations of the evolution of labor law. The following summary makes no attempt to differentiate between the views of individual authors. It draws on the work of Archibald Cox, Sanford Cohen, and other established experts. ${ }^{54}$

Prior to the 1930's the federal government overtly aided management in its confrontations with labor. This due to the business community's access to political power, the conservative property orientation of the federal courts (in particular the Supreme Court), and the prevailing attitude that what is good for business is good for the economy.

During the 1930's the official policy towards labor was dramatically altered. This resulted in part from a shift in ideology as the Great Depression reduced the public's faith in business. The first indication of the changing atmosphere was Norris-LaGuardia, which reflected a Congressional desire to allow unions and management to solve their disagreements free from judicial interference. NorrisLaGuardia, then, ushered in a brief period of federal government neutrality in labor-management relations. 
With the election of Roosevelt and the advent of the $\mathrm{N}$ e w Deal, government involvement in the economy increased. As part of this growing presence provisions were included in the National Industrial Recovery Act to promote the spread of unionization and collective bargaining. The failure of many employers to comply with the act pointed out the need for a better enforcement mechanism.

As the depression dragged on organized labor's access to political power increased. In 1935, with the $\mathrm{N}$ e w Deal control of Congress at its peak, the NLRA was enacted. The NLRA was designed to encourage collective bargaining and therefore promote industrial peace. It was also expected that the bill would augment the bargaining strength of unions, which would result in higher wages and purchasing power and thus stimulate the economy.

From 1935 to 1947 union membership grew dramatically, in great part because of the favorable legal climate. But the sitdown strikes of the late 1930's, a few unpopular war-time strikes, and a great wave of strikes in 1946 caused a deepening public concern with the power of big unions. In the mid 1940 's there was widespread support for government controls of union activity. Even Congressional friends of labor were in favor of equalizing legislation. The election of 1946 reestablished the political influence of business, and in 1947 the LMRA was passed.

The LMRA introduced the current phase of labor relations law, with the government regulating the activities of both labor and management in an attempt to insure a smooth functioning economy uninterrupted by serious labor strife. The LMRA has not accomplished its objective of curbing the power of big unions, but has proved to be a burden for smaller and weaker unions.

\section{APPENDIX B}

\section{Definitions}

- Business unionism refers to the tendency of United States unions to concern themselves only with issues of wages and fringe benefits rather than becoming involved in radical demands or working class movements.

- A closed shop exists when a worker is required to be a union member as a condition of employment.

- Company unions are, employee organizations established and controlled by the employer, usually as a way to avoid recognizing a legitimate union.

- A Craft Union is composed of workers who share a specific skill, such as carpentry.

- $\quad$ "Featherbedding" is a term coined by management to refer to union demands for pay for work not performed. The concept is a tricky one however. For instance, if a union demands that four workers be assigned to a certain task instead of three (perhaps for safety reasons), the employer might claim that the fourth person is not needed and therefore is "featherbedding".

- An industrial union organizes and represents all of the workers in a specific industry regardless of skill.

- A jurisdictional strike is a strike by one union to protest an employer's decision to sign a contract with another union, or to assign work to members of another union.

- Secondary boycotts involve a refusal of workers to use material produced by a firm (other than their own employer) involved in a dispute with its employees.

- A secondary strike is a strike by employees of one firm in support of a strike by employees of another firm.

- A union shop exists when a worker is required to join a union within a specified period (usually 90 days) after becoming employed.

- A wildcat strike is a walkout by workers which is unauthorized by the union and-or breaks a collective bargaining contract. 


\section{Sources}

1. Benjamin Aaron and Paul Meyer, "Public Policy and Labor-Management Relations," in A Review of Industrial Relations Research, Vol. II. Industrial Relations Research Association, 1971, 1-60.

2. "American Labor in the 1940's," Radical America, Vol. 9, nos. 4-5, 1975.

3. Stanley Aronowitz, False Promises, McGraw Hill, 1973-

4. Irving Bernstein, The Lean Years, Houghton Mifflin Co., 1960.

5. Irving Bernstein, Turbulent Years, Houghton Mifflin Co., 1971.

6. Richard Boyer and Herbert Morais, Labor's Untold Story, United Electrical, Radio and Machine Workers of America. 1955.

7. Douglass Brown and Charles Myers, "Historical Evolution, in Public Policy and Collective Bargaining, Industrial Relations Research Association, 1962. 1-27.

8. Sanford Cohen, "An Analytical Framework for Labor Relations Law,' Industrial and Labor Relations Review, Vol. 14, 1961, 350-62.

9. Sanford Cohen, Labor Law, Charles Merrill Books, 1964.

10. Archibald Cox, "Law and the National Labor Policy," University of California, Los Angeles, Institute of Industrial Relations, Monograph No. 5, 1960.

11. Walter Daykin, "The Legal Aspect of Strikes," Labor Law Journal, 1960 739-52.

12. Julius Getman, "The Protection of Economic Pressure by Section 7 of the National Labor Relations Act." University of Pennsy/vania Law Review, Vol. 115, 1967, 1195-1250.

13. George Hildebran, "Collective Bargaining and the Antitrust Laws," in Public Policy and Collective Bargaining, Industrial Relations Research Association, 1962. 152-81.

14. Vladimir Lenin, "State and Revolution," in Essential Works of Marxism, Bantam, 1971.

15. Harry Millis and Emily Brown, From the Wagner Act to Taft-Hartley, University of Chicago Press, 1950.

16. Broadus Mitchell, Depression Decade, Harper and Row, 1947.

17. James O'Connor, The Fiscal Crisis of the State, St. Martin's Press. 1973.

18. Palo Alto Law Commune, Radical Labor Law: A Bibliography With Comments, 1973, $1263 \mathrm{EI}$ Camino Real, Menlo Park, California 94025.

19. Art Preis, Labor's Giant Step, Pathfinder Press, 1972.

20. Arthur Schlesinger, Jr., The Coming of the New Deal, Houghton Mifflin Co., 1959.

21. Clyde Summers, "A Summary Evaluation of the Taft-Hartley Act, Industrial And Labor Relations Review, Vol. 11, 1958, 405-12.

22. Paul Sweezy, The Theory of Capitalist Development, Monthly Review Press. 1942.

23. Philip Taft, The AFL from the Death of Gompers to the Merger, Harper and Brothers, 1959.

24. United States Department of Labor, "Handbook of Labor Statistics 1974" Bureau of Labor Statistics. Bulletin No. 1825, 1974.

25. United States Department of Labor, 'The President's National Labor Management Conference," November 5-30, 1945, "Division of Labor Standards," Bulletin No. 77, 1946.

26. Harris Warren, Herbert Hoover and the Great Depression, Oxford University Press, 1959.

27. James Weinstein, The Corporate Ideal and the Liberal State, Beacon Press, 1968.

1 For example see Bernstein, Turbulent Years. pp. 788-9.

2 For a more thorough treatment of the theory of the state, see Lenin, O'Connor, Sweezy (Chapter 13), and Weinstein.

${ }^{3}$ Hildebrand, pp. 153-6.

4 Brown and Myers, pp. 3-4.

5 Boyer and Morais, p. 120. 
6 Hildebrand, pp. 153-6.

7 Brown and Myers, p. 5.

8 Boyer and Morais, pp. 205-9.

9 Bernstein, Lean Years, pp. 216-7.

10 Cohen, Labor Law, p. 143.

11 Bernstein, Lean Years, pp. 216-7.

12 Warren, pp. 191-2.

13 Bernstein, Lean Years, p. 414.

14 Schlesinger, p. 3.

${ }^{15}$ For more on the National Recovery Administration, see

Mitchell, pp. 228-67.

16 Schlesinger, p. 92.

17 Bernstein, Turbulent Years, p. 3.

18 For more details on these campaigns see Bernstein, Ibid., pp. 37-91.

19 Mitchill, pp. 268, 271-3; United States Department of Labor, "Handbook...," p. 366

20Cohen, Labor Law, pp. 145-7.

21Bernstein, Turbulent Years, p. 185

22lbid., pp. 199-200.

23 Ibid., pp. 217-317

${ }^{24}$ Preis. pp. $19-33$

25 Cohen, Labor Law, pp. 150-1.

26Schlesinger, p. 404.

27Taft, p. 128

28 Bernstein, Turbulent Years, pp. 336, 342-3.

29 Taft, p. 125

30 Bernstein, Turbulent Years, p.646, Millis and Brown, pp. 33, 44.

31 Bernstein, Ibid., pp. 642-3, 647, Millis and Brown, p. 283.

32 Bernstein, Ibid., p. 648; Millis and Brown, pp. 43, 61.

33 Millis and Brown, p. 260.

34 Bernstein, Turbulent Years, pp. 401, 697.

35 Ibid., p. 500.

36 For more details on these and other $\mathrm{ClO}$ activities see Bernstein, Ibid., pp. 432-634, and Boyer and Morais, pp.

290- 328.

37 United States Department of Labor, "Handbook...," p. 366.

38 Cohen, Labor Law, p. 166.

39 Bernstein, Turbulent Years, pp. 601-3-

40 Ibid., pp. 602, 613, 727-9, 741-6.

41 Boyer and Morais, pp. 324-5, Millis and Brown, pp. 283-4

42 Millis and Brown, pp. 284, 348.

43 Ibid., pp. 354-5.

44 "American Labor in the 1940's," pp. 3-114.

45 Boyer and Morais, p. 344; United States Department of Labor, "Handbook...," p. 367.

46 Cox, p. 13.

47 Millis and Brown, p. 364; United States Department of Labor, "President's....."

48 Millis and Brown, pp. 364-5, 370.

49 Cohen, Labor Law, pp. 172-9.

50 Taft, p. 272.

51United States Department of Labor, "Handbook...," pp. 366-8.

52 Boyer and Morais, pp. 350-65, 370.

53For an expanded discussion of these issues see Aronowitz, pp. 214-226. 
54 Based on: Aaron and Meyer, a review of recent research on public labor policy, Brown and Myers, a summary of the historical evolution of labor law, "An Analytical Framework " a theoretical treatment of the development of labor law, Cohen, Labor Law, a standard text; Cox, a monograph which is the classic work in the field; and Summers, an evaluation of the impact of the LMRA. 